AGRO EKONOMI, Vol 30, Issue 1, June 2019, Page.13-26

DOI : http://doi.org/10.22146/ae.41665

ISSN 0215-8787 (print), ISSN 2541-1616 (online) Available at https://jurnal.ugm.ac.id/jae/

\title{
THE TRADE OF INDONESIAN SPICE COMODITIES IN INTERNATIONAL MARKET
}

\author{
Herdiana Anggrasari ${ }^{1}$, Jangkung Handoyo Mulyo ${ }^{2}$ \\ ${ }^{1}$ Master Student in Agricultural Economics, Faculty of Agriculture, \\ Universitas Gadjah Mada \\ ${ }^{2}$ Departement of Socioeconomics, Faculty of Agriculture, Universitas Gadjah Mada \\ Jl. Flora No. 1 Bulaksumur, Yogyakarta \\ herdianaanggrasari@mail.ugm.ac.id
}

Submitted : 13 December 2018 ; Revised : 11 February 2019;

Accepted: 21 March 2019

\begin{abstract}
This research aims to (1) observe the trade patterns and domination export in the spice commodities between Indonesia in international market and the countries as its main trade partners, and (2) observe the performance of the export and import in Indonesian spice industry with its trade partner countries. Grubel-Lloyd Index (GLI) was used to detect whether the trade patterns in spice industry is as intra-industry or as inter-industry as well as to figure out the domination of Indonesian spice commodity export to its trade partner countries. The performance of the export and import in spice industry could be analyzed by using the share of export and import between Indonesia and its trade partner countries. The secondary data were used in this study, obtained from UNComtrade in a 15year period (2002-2016) by concerning in the number of the main trade partner countries. The results of the research showed that the trade of Indonesian spice commodities in international market and among its main trade partners is categorized as a partial industry. Indonesia overall dominates the spice trade with its main trading partners; thus, the trade balance of Indonesian spice commodities is surplus. It is only with China and India in which the trade pattern is categorized as intra-industry. Government needs to do some various efforts to increase the exports of Indonesian spices in the international market by developing market intelligence and enhancing the role of attachés in the spice trade diplomacy in the partner countries and potential countries.
\end{abstract}

Keywords: Grubel-Lloyd Index, international trade, intra-industry trade, spice

Anggrasari, H. \& Jangkung, H.M. (2019). The Trade of Indonesian Spice Comodities in International Market. Agro Ekonomi 30(1) : 13-26

\section{INTRODUCTION}

Every country has many resources causing commodities traded in international market are various according to comparative advantages of each country. This explanation is better known as the Heckscher-Ohlin Theory(Krugman and Obstfeld, 2006). A lot of empirical studies and research have been conducted on international trade and the importance of comparative advantage in international trade (Wang 
and Liu, 2015). This theory does not explain that there are some countries that have identical production, but these countries can still trade mutually beneficial because even though some countries produce a number of products in the same industry, most of their products experience differentiation (not homogeneous). As a result, international trade mostly occurs in the exchange of products that are different from the same industry called intra-industrial trade (Turkcan and Ates, 2010; Jambor and Leitão, 2016).

Indonesian spice commodities are one of the commodities in the plantation sub-sector offering a great opportunity to be marketed globally. As a spice producer, Indonesia is potential to be a world exporter of spices that can contribute positively to the economy. From 1989 to 2016, the trend of world demand for spice commodities tended to increase every year with a demand rate of $10.21 \%$ per year. In thr future, the demand for natural materials including spices in the world is expected to increase along with the growth of population, economy, health demand, the price of synthetic products and awareness about environmental sustainability (Ferry, 2013)

The increase in world demand for spice commodities is in line with the increase in the exports of Indonesian spices in the international market. Based on data from UNComtrade (2018), the average of growth rate of Indonesia's exports increased by $8.23 \%$ per year. Pepper became one of the leading export commodities of Indonesian spices with export share of $56 \%$ from the total Indonesian spice exports with pepper export value of 441.35 million US \$ and pepper import value of 62.89 million US \$. Thus, half of the spice trade profits of Indonesian spices are obtained from pepper trade. Other spice commodities such as vanilla, cinnamon, nutmeg and biopharmaca also provide trade surpluses with the annual average rate of increase in exports within the period of 2002-2016 were $17.76 \% ; 15.77 \% ; 10.35 \%$; and $25.77 \%$ respectively, only cloves having a deficit in the trade balance in 2011, 2012 and 2016. In 2016 Indonesia's cloves suffered a deficit of US \$ 19 million. Based on these data, Indonesian spice commodity exports in aggregate have a positive growth trend. However, it also needs to be monitored regularly since the growth trend of Indonesia's spice commodity imports is greater than its exports. Indonesian spice commodity imports have an import growth rate of $111.12 \%$ per year. It shows that spice commodities are still prospective in both international and domestic market. Chasanah et al., (2017) stated 
that one of the spice commodities still having good potential and opportunity is biopharmaca due to the low competition. Besides, spices can only be planted in certain countries, not all countries can cultivate them. Hence, they have specific characteristics according to its endowment factor. Many commodities are traded in global market, one of which is spice commodities. Spices include a number of commodity groups that have an important role to support human food needs. It is estimated, until now, that there are 400-500 types of spices in the world. One of them is planted in Southeast Asia which makes this region become the center of world spices. Some of the important spices from Southeast Asia are Javanese cardamom, cinnamon, cloves, ginger, nutmeg, black pepper and others (Hakim, 2015).

In the liberalization era, to compete in a similar industry, Indonesian spice commodities have to increase their export share by having a distinct excellence compared to the competitors from the other countries. The natural excellence owned by Indonesia is related to the abundant number of labours, raw materials as well as the distinctive characteristics of Indonesian spices which are not possessed by all countries. Also, Indonesia has a quite high spice production. It is one of the 5 largest producers of spices worldwide, consisting of cinnamon, cloves, nutmeg, pepper, and vanilla. They have great opportunities and potential to be developed. Indonesia has an opportunity to take the advantage of export opportunities in the widely open international market and can expand its market share. On the other hand, Indonesia must face a challenge to be able to improve the performance of spice commodities considering the low export contribution in comparison to the commodities in other agricultural sectors. In 2016, Indonesian spices only contributed to $2.7 \%$ of total agricultural exports, although in 1997 it accounted for $3.88 \%$. It indicates that the performance of Indonesian spices declines.

Not many empirical studies of intra-industrial trade were found -particularly in spice commodities. Kurniawan and Setyari (2018) reviewed the intra-industry trade related to the cosmetics industry; while; Hermawan (2015), conducted a research on spice commodities, but the study was in the scope of the ASEAN market sphere in the post and pre-global crisis period within a 9-year period (2005-2013). In this study, there was a renewal of the year, namely in 2012-2016 in which the scope of research was expanded to the international market. Hermawan(2015) examined the trade pattern in the spices in Indonesian with its trade partner 
countries. Research on Indonesian spice commodities in the international market is important to observe the trade pattern of spice industry between Indonesia in the international market and the main trade partners countries, to learn the dominance of Indonesian spice commodity exports with trade partner countries and to learn the performance of the export and imports in the Indonesian spice industry with its trade partner countries. Therefore, this research aims to observe the trade patterns and domination export in the spice commodities between Indonesia in international market and the countries as its main trade partners and observe the performance of the export and import in industry of Indonesia spices with its trade partner countries. This research in turn contributes to the completion of existing research results.

\section{METHODS}

The secondary data were used in this study, obtained from UNComtrade within a 15-year period (2002-2016). The elicited data were the values of the import and export of Indonesian spice commodities in the international market and the values of export and import of Indonesian spice commodities with 20 main trade partner countries (United States, Vietnam, India, the Netherlands, Singapore, Germany,
France, Japan, Malaysia, China, Saudi Arabia, Canada, Italy, Pakistan, South Korea, Bangladesh, Brazil, Thailand, United Arab Emirates, and Turkey) in the international market. The spices commodities used were agricultural sector commodities including six groups of spice commodities, namely pepper, chili, and capsicum (HS 0904), vanilla (HS 0905), cinnamon (HS 0906), cloves (HS 0907), nutmeg, mace, cardamom (HS 0908), and biopharmaca (HS 0910) based upon the code for the Harmonized Commodity Description and Coding System (HS).

\section{Analytical Method}

To find out whether international trade in spice commodities is categorized into intra-industry or inter-industry, an analysis was conducted by means of a formula proposed by Grubel and Llyod (1971). The indicators of Intra-Industry Trade (IIT) and Grubel-Lloyd Index (GLI) were used to identify the countries involved in the same industry (Yazdani and Pirpour, 2018)institutional arrangements associated with the energy market and market integration can improve the distribution of energy products and boost bilateral trade productivity in energy products. Furthermore, intra-industry trade (IIT. GLI formula is presented as follows: 
$G L I_{i}=\left[1-\frac{\left|X_{i}-M_{i}\right|}{\left(X_{i}+M_{i}\right)}\right] \times 100$

Remark:

$X_{i}=$ The value of commodity exports $\mathrm{i}$

$\mathrm{M}_{\mathrm{i}}=$ The value of commodity imports $\mathrm{i}$

$\mathrm{i}=$ The spice commodities in HS four digitnamely pepper, chili, and capsicum (HS 0904), vanilla (HS 0905), cinnamon (HS 0906), cloves (HS 0907), nutmeg, mace, cardamom (HS 0908), and biopharmaca (HS 0910).

This index was valued between 0 and 100 . The index was valued at lowest (zero) if the trade only occurred in one direction; in contrast, it would be valued at maximum (one hundred) if the trade is balanced and has high trade integration between the two countries (Yazdani and Pirpour, 2018).
RESULTS AND DISCUSSION Intra-industry Trade of Indonesian Spice Commodities in International Market

A country might have the same comparative advantage with another country so that they produce the type of products in the same industry, but most of the products can experience differentiation due to the differences in economies of scale in each country. Therefore, the international trade that occurs at most involves the exchange of differentiated products from the same industry called intra-industry trade (Salvatore, 2007). The existence of intra-industry trade will benefit consumers because of the creation of more choices leading to better quality products, and prices will be cheaper

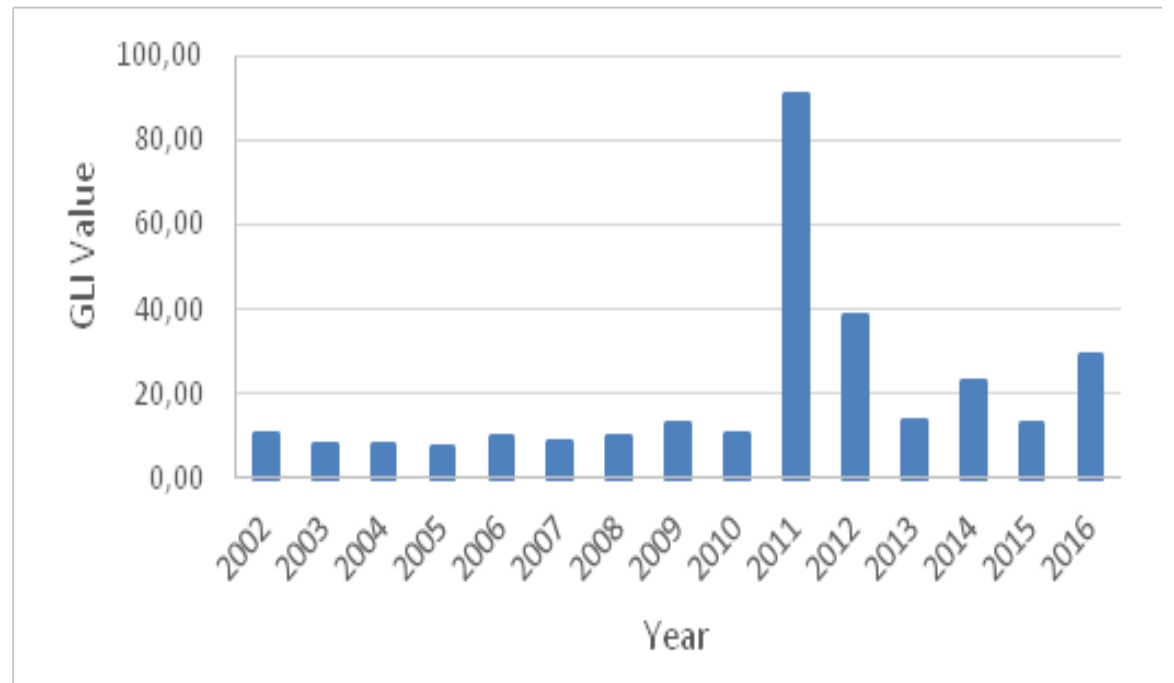

Figure 1. The Development of Indonesia GLI Values in the Trade of Spice Commoditiesin International Market in Period of 2002-2016 Source: UN Comtrade (edited), 2018 
due to the increasing economic scale of each country. On the other hand, trade that occurs in different industries is called as inter-industry trade which appears due to the existence of different resources. Therefore, the trade is based on comparative advantages of each country. The existence of inter-industry trade causes each country to produce the variety of products that have a comparative advantage efficiently at a lower cost and import other products which cannot be produced by themselves independently.

Based on the calculation carried out over a 15-year period (20022016), it was found that the GLI value of the Indonesian spice industry in the international market was fluctuative and tended to experience an average decline by 0.17 per year. The average GLI value of Indonesian spice industry was $19.50 \%$, indicating that the trade of Indonesian spices in international markets is pointing into an inter-industry trade (Figure 1).

As shown in Figure 1 in 2002-2010 the average GLI value was $9.43 \%$ with an average rate of GLI value added annualy of $2 \%$. But in 2011 Indonesia's GLI value rose sharply to $90.90 \%$ showing high level of intraindustry trade. After 2011, there was a decrease in GLI value with an average value from 2012-2016 of $14.76 \%$ and an average rate of GLI value increment of $7 \%$ per year. The increase in GLI value in 2011 was due to an increase in the value of imported spices commodities, resulting high trade integration. This increase occurred because of the demand for domestic spice commodities. The domestic industry was more interested in processed spice products than raw materials (Malau, 2011). A sharp increase in imports occurred in clove commodities. According to UNComtrade data in 2010, the number of Indonesia's clove imports was only around 1.3 million US \$, but in

Table 1. The Development of Indonesia GLI Values in the Trade of Spice Commodities in International Market in Period of 2002-2016

\begin{tabular}{ccccccc}
\hline \multirow{2}{*}{ Year } & \multicolumn{7}{c}{ HS Codes } \\
\cline { 2 - 7 } & 0904 & 0905 & 0906 & 0907 & 0908 & 0910 \\
\hline $2002-2006$ & 12.83 & 17.51 & 4.59 & 1.25 & 0.56 & 17.65 \\
$2007-2011$ & 15.78 & 12.23 & 8.57 & 6.43 & 0.54 & 32.28 \\
$2012-2016$ & 21.23 & 6.37 & 28.15 & 1.77 & 33.28 & 23.21 \\
\hline Mean & 16.62 & 12.04 & 13.77 & 3.15 & 11.46 & 24.38 \\
\hline
\end{tabular}

Source: UN Comtrade (edited), 2018

Information: pepper, chili, and capsicum (HS 0904), vanilla (HS 0905), cinnamon (HS 0906), cloves (HS 0907), nutmeg, mace, cardamom (HS 0908), and biopharmaca (HS 0910) 
2011 it rose sharply to US \$ 345 million, and in 2012 it decreased to 110 million US \$. The high value of clove imports was due to the increase in clove prices in the international market as a result of the decline in world clove production. Clove prices increased from 3.65 US \$ / kg to 8.11 US \$ / kg in 2011. Clove imports were carried out due to the declining of Indonesian clove production. FAO data shows that in 2011 there was a decrease in the number of clove production by 26\% (98 thousand tons to 72 thousand tons). In addition, there was a decrease in clove productivity by $29 \%$. In 2010 Indonesia's clove productivity reached 0.30 tons / ha and then dropped to 0.21 tons / ha. Tupamahu (2015) stated that in the period of 2008-2011 the comparative advantage of Indonesian cloves was lower than the world average and had no competitiveness. After 2011, there was an increase in clove production with an average rate of production increase of $14.7 \%$ per year so that clove imports declined. Whereas in 2011, the commodity group of pepper, chili and capsicum, cinnamon, nutmeg, mace, cardamom and biopharmaca did not increase significantly. The increase in imports of all these commodities in 2010 was around 22.3 million US \$, then in 2011 it was 48.6 million tons. In 2012, the value of imports increased to US $\$ 51$ million (UNComtrade, 2018).
The development of Indonesia GLI value in the trade of spice commodities in the international market in 2002-2016 (Table 1) in each commodity showed a different value. The GLI value of all spice commodity groups was low. However, the spice trade in the commodities such as pepper, chili, and capsicum, vanilla, cinnamon, clove, nutmeg, mace, cardamom, and biopharmaceutical was categorized as inter-industry. In the commodity groups of pepper, chili and capsicum, cinnamon, and nutmeg, mace, cardamom, there was an increase in GLI values in each period.

The increasing value of GLI shows that there has been an increase in Indonesia's trade integration in these commodities on the international market. It can be seen from the increasing trade value of Indonesian spice commodities in the international market. The value of exports and imports of spice commodities in 2002 was around 190 million US \$ and 10.5 million US $\$$ and then became 774.5 million US \$ and 132.1 million US \$ in 2016 (UNComtrade, 2018). Increasing trade integration shows that the available products are differentiated (Nizar and Wibowo, 2015). In contrast to vanilla which has a decreasing GLI value in each period. The decline in the value of GLI of vanilla commodities was caused by a decrease in Indonesia's Therefore 
clove commodities became a commodity having a major influence on increasing GLI values in 2011.vanilla imports. Based on the data from UNComtrade (2018), for 15 years (2002-2016) there was a decline in vanilla imports by $14 \%$, despite an increase in vanilla exports by $73 \%$. In clove and biopharmaca commodities, GLI values were fluctuative every period. In 2007-2011, an increase in GLI values occured in clove and biopharmaca commodities, yet in the next period there was a decrease in GLI values.

Based on the results of these studies, it can be seen that the development of trade intensity in Indonesian spice commodity groups in the international market is aggregately included in the interindustrial trade. It means that trade is classified as a trade in different industries. The typicality of spice commodities not owned by all countries is one of the factors that is responsible to the creation of the trade pattern between industries. It shows that the spice commodity group is included as the primary commodities indicating a difference in resources owned by each country.

\section{Intra-industrial Trade of Indonesian Spice Commodities with Major Trading Partners}

Indonesia, a country that produce spices will dominate the export of spice commodities to its trading partner countries. It is caused, some of Indonesia's trading partner countries include South Korea, Japan, Italy, Turkey, Thailand, Canada, Singapore, the United States, France, Bangladesh and the United Arab Emirates are not large in terms of spice production and export in the international market. Other Indonesia's trading partners including Madagascar, Vietnam, India, Tanzania, and China are the biggest suppliers of spices in Indonesia. However, Indonesia still exports spices to Vietnam, India, and China. Most of Indonesian spices are exported to the countries listed in table 2. Therefore the Indonesian spice trade occurring with most of its trading partner countries are inter-industry trade.

Based on the calculation of means of GLI, the Indonesian spice industry with its trade partner countries for 15 years (2002-2016) showed that each partner country had different GLI values. The average value of GLI for 15 years from most of Indonesia's trade partner countries (i.e. United States, Vietnam, India, the Netherlands, Singapore, Germany, France, Japan, Malaysia, Saudi Arabia, Canada, Italy, Pakistan, South Korea, Bangladesh, Brazil, Thailand, United Arab Emirates, and Turkey) was low because the GLI value not until 50\%. It was only China having a GLI value high enough (Table 
2).The meaning of the GLI value is low, which means that the pattern of trade that occurs is tend to be one direction and that means the commodity spices have low trade integration between Indonesia and its trading partner countries According to Astriana and Rahman (2014), if the GLI value is 0 , then the trade occurs in one direction. It can be seen in the GLI value of Saudi Arabia, Canada, and Bangladesh in the period 2007-2011 is worth 0. It shows that in this period Indonesia was not importing any commodities from those countries which can be seen from the absence of Indonesia's import value. Trade that occurs between Indonesia and its trading partner countries is only needed above the comparison of each country.

As seen in Table 2, the highest trade intensity of the spice commodity group in the period of 2002-2006 was found in China with a GLI value of $60.80 \%$ indicating that intra-industry trade between Indonesia and China has occurred so that the trade to be in a twoway trade and started to consider the competitiveness. In each period, China

Table 2. Developments in the Indonesia GLI Values with the Main Trade Partner Countries in Spice Commodity Trade in International Market in Period of 2002-2016

\begin{tabular}{lcccc}
\hline Country & $2002-2006$ & $2007-2011$ & $2012-2016$ & Mean \\
\hline United States & 0.89 & 0.26 & 0.30 & 0.45 \\
Vietnam & 27.75 & 12.95 & 23.14 & 15.27 \\
India & 29.05 & 41.41 & 56.79 & 37.00 \\
Dutch & 0.55 & 0.90 & 1.87 & 0.74 \\
Singapore & 0.75 & 7.05 & 3.51 & 3.46 \\
German & 1.10 & 1.40 & 1.47 & 1.07 \\
French & 0.57 & 2.03 & 0.42 & 2.87 \\
Japan & 3.19 & 1.83 & 0.66 & 1.40 \\
Malaysia & 13.65 & 44.67 & 34.96 & 23.40 \\
China & 60.80 & 40.83 & 74.54 & 52.02 \\
Saudi Arabia & 0.01 & 0.00 & 0.02 & 0.09 \\
Canada & 2.05 & 0.00 & 0.42 & 0.72 \\
Italia & 3.52 & 0.37 & 0.01 & 0.84 \\
Pakistan & 0.64 & 1.47 & 1.32 & 0.85 \\
South Korea & 10.60 & 4.73 & 7.14 & 5.50 \\
Bangladesh & 0.00 & 0.00 & 1.07 & 0.36 \\
Brazil & 0.33 & 12.34 & 40.05 & 10.54 \\
Thailand & 13.67 & 18.12 & 13.48 & 17.83 \\
United Arab & 0.71 & 3.50 & 0.16 & 1.21 \\
Turkey & 10.39 & 6.39 & 13.19 & 9.99 \\
\hline Mean & 9.01 & 10.01 & 13.73 & 9.28 \\
\hline
\end{tabular}

Source: UN Comtrade (edited), 2018 
has showed consistency as an Indonesian trade partner. Distance can be one of the factors influencing trade flows between Indonesia and China. Distance represents transportation costs. If the distance between the two countries is further away, the transportation costs incurred will be even greater, which later on can affect the amount of the commodities traded (Astriana and Rahman, 2014). However, related to the trade performance in both countries on average for 15 years, Indonesia experienced a spice trade deficit with China. It shows that China dominated the spice trade with Indonesia. From 2014 to 2016 the balance of Indonesia spice trade with China experienced a surplus which showed that Indonesia dominated the spice trade in that year. On the other hand, with other trade partners, the performance of the Indonesian spice trade overall had a surplus showing that Indonesia has dominated the spice trade with its trade partner countries.
In the period of 2007-2011, the trade intensity between Indonesia and Malaysia and India experienced an increase as indicated by high GLI values. In the period of 2012-2016 Malaysia's GLI value declined and Brazil appeared with a high GLI value. The GLI value of spice commodities between Indonesia and its trade partner countries tended to fluctuate. GLI values among trading partner countries will tend to be stable if these countries have large markets with relatively the same size, high economic development, low exchange rate fluctuations between the two countries, proximity of regions, and similarity in language (Hayakawa et al., 2017)in contrast to what the previous literature has shown, two-way intra-industry trade (IIT. Intra-industrial trade can occur in the same economies,including the size of country influencing the trade patterns as the countries with higher incomes tend to proportionally show the larger trade volume. As seen from the changes in GLI

Table 3. The Change of Indonesia GLI Values with the Main Trading Partner Countries of Indonesia in the Trade of Spice Commodities in International Market

\begin{tabular}{lclc}
\hline & 2002 & & \\
\hline Partner Country & GLI & Partner Country & GLI \\
Vietnam & 99.84 & Vietnam & 22.10 \\
India & 45.59 & India & 53.92 \\
China & 90.85 & China & 59.85 \\
Brazil & 1.62 & Brazil & 67.23 \\
\hline
\end{tabular}

Source: UN Comtrade (edited), 2018

Information: The data shown are only the countries with the high GLI value 
values from 2002 and 2016 (Table 3) there was an increase in the GLI values in several Indonesian trade partner countries, namely India and Brazil.

Indonesia has a spice trading partner relationship with Southeast Asian countries namely Thailand, Vietnam, Malaysia and Singapore. Many commodities of spices are traded among Southeast Asian countries. These countries have geographically close proximity, allowing these countries to have similar natural resources. The similarity makes each country seek differentiation through branding using Geographical Indications, for example Indonesia has a well-known type of pepper namely Lampung Black Pepper and Muntok White Pepper while Malaysian pepper is known as Sarawak Black and Sarawak White. This can provide added value for each country. Whereas with Singapore which is not a spice producing country and has limited land resources, has imported raw spice commodities from several countries, including Indonesia. Imported commodities are mainly vanilla, cinnamon, clove and biopharmaca. Singapore can export spices by importing then processing and then re-exporting (Tupamahu, 2015). In Indonesia, some of the spices traded are still in rawform, such as nutmeg and ginger (Hermawan, 2016). This can reduce the added value of spice commodities and also reduce the quality of spices. (Listriyani, 2015).

Therefore, it is necessary to process spice commodities into products that have added value by differentiating products or by processing raw materials. In the domestic industry there have been many spices made from spices, for example, being ground dry spices formulated, such as for rendang and gulai, there are also dried spices milled from each type of spices, such as chili powder, garlic powder, and ground pepper. In addition there is a differentiation of nutmeg meat products with processed into several types of products such as candied nutmeg, nutmeg dodol, nutmeg candy, nutmeg jam and nutmeg syrup ((Rawis, et. al., 2016)). Indonesian domestic spices commodity industries still need to be increased to increase export value and expand market share.

As shown in Table 3, an increase in the GLI value of spice commodity groups between Indonesia and India and Brazil indicated the more various spice commodity products among the three countries enabling the people to have more choices to buy the products from the spice commodities based upon their needs. Vietnam, meanwhile, experienced a decline in the GLI value in the spice commodity groups. In 2002 the GLI value of Vietnam and Indonesia was considered high, indicating that the 
two countries actively made a trade in spice commodities. The decrease in trade intensity can occur due to a change of people's tastes.

likewise with China, GLI values in Indonesia tend to decline. In 2002 the spice trade between Indonesia and China was the most intensive, namely in clove commodities with a GLI value of 51.79. Unfortunately, in 2016 the intensity of the commodity trade declined. For 15 years (2002-2016), Indonesia had the most imports of nutmeg and biopharmaca commodities. While Indonesia exports spices to China in all commodities. However, during 2002-2013 the value of Indonesian imports tended to be more than the value of Chinese imports. Starting in 2014-2016 Indonesia succeeded in increasing its trade performance so that it could achieve a surplus in spice commodities. However, in nutmeg and biopharmaceutical commodity groups, Indonesia's trade performance still tends to be deficit. The most intensive trade in spice commodities between Indonesia and India is in the pepper commodity group because for 15 years (20022016) the average GLI value was 51.23. In addition to pepper, commodities that are often traded are cinnamon and biopharmaca. The integrity of the spice commodity trade between Indonesia and Brazil for 15 years also increased.
In 2002 Brazil's GLI value was only 1.62 then increased in 2016 to 67.23. This is because in 2002 to 2010 Indonesia did not import commodity spices from Brazil. Since knowing 2011, Indonesia began importing Brazilian spices in the pepper and clove commodities. According to FAO data in 2016, Vietnam, India, China, and Brazil are among exporters of spice commodities with different commodity specifics. Brazil is a clove exporter; India exporters of pepper, nutmeg and biopharmaca; Vietnam export of pepper, cinnamon, nutmeg; and China exporters of pepper, cinnamon, biopharmaca. Some ways that can be done by Indonesia to strengthen exports is by increasing the competitiveness of these commodities by increasing the quantity and quality of Indonesian spices. In addition, a survey is needed to determine consumer preferences so that Indonesian spice producers can meet domestic demand so as to reduce imports.The low GLI value shows that the intra-industry trade of spice commodities between Indonesia and its trade partners is still in one-way direction and still dominated by one country. In this study, Indonesia tended to dominate the spice trade with its trade partner countries. Indonesia is one of the spice exporters in the international market and is included in the top 5 in the export of pepper, nutmeg, clove, cinnamon and vanilla. Spices are the 
commodities that not all countries have due to the geographical factors and this has made only a few countries to be able to cultivate such spices. The low GLI value also shows that the trade of Indonesian spices with trade partners is still dominated by the comparative excellence from Indonesian.

The high GLI value between Indonesia and China showed a twoway trade. This value also showed the high demand for spice commodities in both countries due to variations or differentiations in spice commodities and showed that the two countries began to consider the comparative competitiveness in the same industry; thereby increasing a product specialization. The high intensity of trade in the same industry shows the product differentiation and economies scale that create the different market structures in each country. Cabral et. al.,(2013) states that each country produces several products that are different from the economies of scale of each country and each country also has different consumer preferences; thus creating intra-industrial trade. This then encouraged Indonesia and China to produce several different commodities in the same industry. Also, the existence of trade between countries in one particular region can increase the GLI value.

\section{CONCLUSION AND SUGGESTION}

The Indonesian spice trade partner countries inwas establih the period of 2002 to 2016 included the United States, Vietnam, India, the Netherlands, Singapore, Germany, France, Japan, Malaysia, China, Saudi Arabia, Canada, Italy, Pakistan, South Korea, Bangladesh, Brazil, Thailand, the United Arab Emirates, and Turkey with the total import of $91.40 \%$ of total Indonesia exports. Based on GLI analysis, the trade of Indonesian spice commodities in the international market and among the main trade partners overall was partially inter-industrial and the GLI value tended to increase between Indonesia and its trade partner countries. Indonesia dominated the spice trade with its main trade partner countries making the trade balance to have a surplus, except with China. Meanwhile, the spice commodities trade of Indonesia with China and India was considered intraindustrial meaning that the trade has taken place in a two-direction trade.

The trade of Indonesian spices with most of its trade partner countries is included as the inter-industry, but Indonesia must remain alert with the performance of commodity exports to its partner countries. Government needs to do some various efforts to reinforce the increase of exports of Indonesian spices in the international market. One of the 
efforts that can be done is by developing market intelligence - a strategy to obtain information on the spice commodity market by collecting data and analysing the markets in accordance with the current market condition. In addition, it can be done by enhancing the role of attachés in the spice trade diplomacy and by organizing some exhibitions and socialization of Indonesian spice products in the partner countries and potential countries, especially in Vietnam, China, India and Brazil. While in the country, Indonesia needs to increase the quantity and quality of Indonesian spice commodities, and a survey is needed to determine consumer preferences so that Indonesian spice producers can meet domestic demand so as to reduce imports.

\section{REFERENCE}

Astriana, \& Rahman, A. (2014). Analisis Perdagangan Intra Industry Indonesia-Cina (Tahun 2000-2014). Jurnal Administrasi Negara, 20(1), 22-31.

Cabral, M., Falvey, R., \& Milner, C. (2013). Endowment Differences and the Composition of Intra-Industry Trade. Review of International Economics, 21(3), 401-418. https://doi. org/10.1111/roie.12044
Chasanah, N., Mulyo, J. H., \& Darwanto, D. H. (2017). Competitiveness and Export Similiarity of INDONESIA Horticulture in the ASEAN+3. Agro Ekonomi, 28(1), 32-47.

Ferry, Y. (2013). Prospek Pengembanga Kayu Manis (Cinnamomun Burmanii L) di Indonesia.SIRINOV, 1(1), 11-20.

Hakim, L. (2015). Rempah \& Herba. Yogyakarta: Diandra Pustaka Indonesia.

Hayakawa, K., Ito, T., \& Okubo, T. (2017). On the Stability of Intra-Industry Trade. Journal of the Japanese and International Economies, 45(2017), 1-12. https://doi.org/10.1016/j. jjie.2017.05.001

Jambor, A., \& Carlos Leitão, N. (2016). Industry-Specific Determinants of Vertical Intra-Industry Trade: the Case of EU New Member States' Agri-food Sector. Post-Communist Economies, 28(1), 34-48. https:// doi.org/10.1080/14631377.2015. 1124553

Krugman, P. R., \& Obstfeld, M. (2006). International Economics Theory and Policy. Boston: Elm Street Publisher Service Inc. 
Kurniawan, I. P., \& Setyari, N. P. W. (2018). Determinan Intra-Industry Trade Komoditi Kosmetik Indonesia dengan Mitra Dagang Negara ASEAN-5. E-Jurnal EP Unud, 7(1), 58-90.

Malau, S. (2011). Kementrian Perdagangan Kembangkan Industri Rempah. Retrieved April 8, 2018, from http://www.tribunnews. com/bisnis/2011/11/18/ kementrian-perdagangankembangkan-industri-rempah

Rawis, B. L. M., Talumingan, C., \& Laoh, E. H. (2016). Diferensiasi Produk Daging Buah Pala dan Grand Merciful Buiding. Cocos, 6(1), 1-16.

Salvatore, D. (2007). International Economics. New Jersey: Wiley and Sons.

Tupamahu, Y. M. (2015). Analisis Daya Saing Ekspor Cengkeh Indonesia di Kawasan ASEAN dan Dunia. Agrikan, 8(1), 27-35.

Turkcan, K., \& Ates, A. (2010). Structure and Determinants of Intra-Industry Trade in the U.S. Auto-Industry. Journal of International and Global Economic Studies, 2(2), 15-46.

Wang, P., \& Liu, X. (2015). Comparative Analysis of Export Similarity Index Between China and EU. In International Conference on Management Science and Management Innovtion, 222-227 China: Atlantis Press. https://doi. org/https://doi.org/10.2991/ msmi-15.2015.42

Yazdani, M., \& Pirpour, H. (2018). Evaluating The Effect of IntraIndustry Trade on The Bilateral Trade Productivity for Petroleum Products of Iran. Energy Economics, $x x x(2018), 1-7$. https://doi. org/10.1016/j.eneco.2018.03.003 